\title{
REALISING CHILDREN'S RIGHTS TO LEGAL REPRESENTATION AND TO BE HEARD IN JUDICIAL PROCEEDINGS: AN UPDATE
}

\author{
JuLia SLOTH-NieLSEN ${ }^{*}$
}

\section{ABSTRACT}

South Africa still has some way to go towards ensuring that children's rights to legal representation and to be heard are fully implemented in relation to judicial proceedings affecting them. Nonetheless, some emerging practices point to an ongoing expansion of the realisation of these rights. This article charts some key developments in law, policy and implementation that constitute such practices. The article also argues that apart from merely serving as the child's voice in the courtroom setting, effective child lawyering is additionally contingent on a commitment to seeking out children in need of services, on an emphasis more broadly on stakeholder relationships in the sector, and a willingness to adjust to changing circumstances.

\section{INTRODUCTION}

Two distinct children's rights have been established in international law and in South African law: the right of a child to be heard in any judicial proceedings affecting the child, and the right of a child accused of an offence to be legally represented. This article considers promising practices for the implementation of children's rights to be heard and to legal representation arising from the South African context. A crucial aspect of implementation is domestication of the rights in national legislation and judicial precedent, followed by implementation in practice. This is obviously constrained by available resources in our country. Further, though, historically there has been little in the way of precedent for providing such representation on any scale to largely indigent children.

In South Africa, the Constitution of the Republic of South Africa, 1996 has provided, in s 28(1)(h), that children affected by civil proceedings have a right to legal representation at State expense if substantial injustice would otherwise result. Successful models for implementation of this right are crucial to the realisation of the right. In the period shortly after the advent of the Constitution, some academic writing and legislative reform concerning access to legal representation for children saw the light of day. ${ }^{1}$ However, the

* Professor and Dean, Faculty of Law, University of the Western Cape.

1 See, for instance, FN Zaal Do Children Need Lawyers in the Children's Courts Publication of the Children's Rights Project, Community Law Centre, University of the Western Cape (1996); FN Zaal 'When Should Children be Legally Represented in Care Proceedings? An Application of Section 28(1)(h) of the 1996 Constitution' (1997) 114 South African Law Journal 334; J Sloth-Nielsen \& B Van Heerden 'The Child Care Amendment Act 1996: Does it Improve Children's Rights in South Africa?' (1996) 12 SAJHR 649. 
implementation of this right has been in a state of transition, necessitating an updated examination, and providing the motivation for this article. This article therefore reviews recent legislative developments which have taken place to further the child's right to legal representation, examines some jurisprudence in which lawyers and their role in the representation of children have featured, and describes practical developments that have occurred in relation to the provision of legal representation for children.

It has become apparent, it will be shown, that the main role-player designated to provide legal representation to children in South Africa is the Legal Aid Board (LAB). Practical models of how these services are provided are in a state of change as the LAB rolls out an ambitious plan for LAB Children's Units, that will represent children in criminal courts, children's courts and civil proceedings in general; it appears that more children than ever before are being represented across the country. These plans are pragmatic and soberly budgeted, aiming to maximise resources while ensuring specialisation and quality of service. Consequently the model the LAB is attempting to follow in meeting its constitutional and legislative obligations is key; however, this article also considers briefly a number of other ways of providing legal services to children. ${ }^{2}$

University law clinics and non-governmental organisations (NGOs) still play an important role, and follow slightly different models. Impact litigation by NGOs is setting important precedents for children's rights in particular, and appropriately, in relation to the legal representation of children to represent both children's interests and give voice to their views. With the pending promulgation of the Children's Act 38 of 2005, and the likely completion of the Child Justice Bill, currently before Parliament, it is predicted that children's participation in judicial proceedings is destined to assume a far more central role than has ever before been the case.

\section{Legal Representation of Children in CRiminal AND Civil MATTERS}

\section{(a) International and constitutional law}

Articles 40(b)(ii) and (iii) of the United Nations Convention on the Rights of the Child (the CRC) provide that every child accused of having infringed the penal law is 'to have legal or other appropriate assistance in the preparation and presentation of his or her defence' and is 'to have the matter determined without delay by a competent, independent and impartial authority or judicial body in a fair hearing according to law, in the presence of legal or other

2 This article is based on a report initially commissioned by the African Child Policy Forum. The assistance of Jean Redpath in undertaking the fieldwork is noted gratefully. Parts of the study reflect the views of various practitioners in different provinces who were identified as being specialists in providing legal services to children who were interviewed in November 2007. They have requested to remain anonymous. 
appropriate assistance and, unless it is considered not to be in the best interest of the child, in particular, taking into account his or her age or situation, his or her parents or legal guardians'.

The CRC further makes it clear that a child is specifically entitled to legal assistance as soon as the child is deprived of liberty; art 37(d) provides that every child deprived of liberty has the right to "prompt access to legal and other appropriate assistance'. This has its echo in art 17(2)(c)(iii) of the African Charter on the Rights and Welfare of the Child (the African Children's Charter), which provides that State Parties to the African Charter shall ensure that every child accused of infringing the penal law 'shall be afforded legal and other appropriate assistance in the preparation and presentation of his defence'.

Child participation under art 12 of the CRC is regarded as being one of the four pillars of the treaty, heralded as giving the CRC its 'soul'. ${ }^{3}$ Article 12(2), in particular assures to the child 'the opportunity to be heard in any judicial or administrative proceedings affecting the child, either directly, or through a representative or an appropriate body, in a manner consistent with the rules of national law'. This provision is echoed in art 4(2) of the African Children's Charter, which provides that 'in all judicial or administrative proceedings affecting a child who is capable of communicating his/her own views, an opportunity shall be provided for the views of the child to be heard either directly or through an impartial representative as a party to the proceedings, and those views shall be taken into consideration by the relevant authority in accordance with the provisions of appropriate law'.

As mentioned, s 28(1)(h) of the Constitution incorporates, to a degree, the principles contained in art 12(2) of the CRC. However, the particular way in which the section has been worded has important implications. First, the criterion for whether State-funded legal representation in civil proceedings affecting the child is a constitutional imperative is the same as the constitutional criterion applicable to State-funded legal representation in criminal cases (ie whether substantial injustice would otherwise result). This, it has been pointed out, narrows the scope of the right in comparison with the more expansive elaboration in both art 12(2) of the CRC and art 4(2) of the African Children's Charter, which are not limited in this way. ${ }^{4}$

Secondly, it has been observed that the constitutional right is awarded irrespective of whether the child is a party to the proceedings or is otherwise directly involved, and consequently contemplates instances where children are 'affected' by proceedings, which must include judicial proceedings where they are not directly before court. ${ }^{5}$ This accords well with the wording of art 12(2) of the CRC. Lastly, s 28(1)(h) makes reference to legal representatives

3 J Sloth-Nielsen 'Ratification of the United Nations Convention on the Rights of the Child: Some Implications for South African Law' (1995) 11 SAJHR 401.

4 J Sloth-Nielsen \& B Mezmur 2+2=5? Exploring the Domestication of the CRC in South African Jurisprudence (2002-2006)' (2008) 16 International Journal of Children's Rights 1.

5 Ibid. 
only, and does not provide for children's views to be heard by other means or via 'non-legal' representatives, in contradistinction to the CRC and the African Children's Charter, both of which appear to contemplate the hearing of children's views by other means. ${ }^{6}$

Children accused of infringing the penal law may avail themselves of the constitutional provision applicable to all detained persons, that is, $\mathrm{s} 35(2)$ which provides for every accused person to choose and be represented by a legal practitioner, and to have a legal practitioner assigned to him or her at State expense for trial if 'substantial injustice would otherwise occur'. The latter right to legal representation in terms of s $35(3)(\mathrm{g})$ is consequently 'both limited in scope and dependent upon a rather vague, predictive ground - the "substantial injustice" test which may prove somewhat difficult to delineate in practice'? It has been argued that where a child is prosecuted in the courts, with the possible result of a criminal record, a substantial injustice will occur if he or she is not legally represented. ${ }^{8}$ Further suggested criteria include whether a child may be liable to be deprived of his or her liberty by placement in any of the institutions linked to the juvenile justice system, ${ }^{9}$ and where a child might be below the age of 14 years and therefore subject to the rebuttable presumption that he or she lacks criminal capacity. ${ }^{10}$ The criteria for awarding State-funded legal representation to children in the criminal justice system has recently been the subject matter of some debate, however, and is therefore discussed in section II(b)(iv) of this article.

\section{(b) Giving effect to the constitutional right in municipal legislation}

(i) Civil proceedings and the Children's Act 38 of 2005

There are three main types of proceedings in which children's right to legal representation is particularly relevant in the South African context: children's court enquiries, civil proceedings in general where a curator ad litem is appointed, and family law matters.

The Children's Act 38 of 2005, partially promulgated on 1 July 2007, is set to replace the Child Care Act 74 of 1983, which currently provides for the work of the children's courts. The Children's Act provides in s 55 that where a child involved in a matter before the children's court is not

6 In relation to criminal proceedings, General Comment no 10 of the CRC Committee (Children's Rights in Juvenile Justice) released in February 2007 clarifies that a wider notion of representation of children's views is consistent with the CRC, <http://www2.ohchr.org/english/bodies/crc/docs/GC10_en.doc>.

7 N Zaal \& A Skelton 'Providing Effective Representation for Children in a New Constitutional Era: Lawyers in the Criminal and Children's Courts' (1998) 14 SAJHR 539, 541.

8 A Skelton 'Developing a Juvenile Justice System for South Africa: International Instruments and Restorative Justice' (1996) Acta Juridica 180, 190 n52.

9 J Sloth-Nielsen 'Children' in MH Cheadle, DM Davis \& N Haysom (eds) South African Constitutional Law The Bill of Rights (2002) 507, referring to placement in prisons as well as other residential facilities, such as schools of industry or reformatories.

10 South African Law Reform Commission (2000) Report on Juvenile Justice Project 106 at par 11.1611.17, <http://www.doj.gov za/salrc/reports/r_prj106_juvjus_2000\%20jul.pdf $>$. 
represented, and the court is of the opinion that it would be in the best interests of the child to have legal representation, the court must refer the matter to the LAB. ${ }^{11}$ This bare provision seemingly limits the choice of legal representation and, it has been suggested, is 'constitutionally suspect'; however, the provision, which has not yet come into effect, has galvanised the LAB into action and been a key reason for the establishment of LAB Children's Units across the country, discussed in more detail in section III of this article: ${ }^{13}$

This section places an enormous responsibility on the LAB in terms of developing its capacity to fulfil this role. This is however consistent with the LAB's strategic objective of prioritising the legal representation of children in its delivery programme. ${ }^{14}$

Previous attempts to legislate criteria for the appointment of legal representatives for children in children's court inquiries, via amendments in 1996 to the Child Care Act and to the regulations to this Act in $1998,{ }^{15}$ failed due to

11 Of some importance, too, is the provision contained in s 10 , which came into effect on 1 July 2007. It contains the general principle that '[e]very child that is of such an age, maturity and stage of development as to be able to participate in any matter concerning that child has the right to participate in an appropriate way and the views expressed by the child must be given due consideration'.

12 Note 4 above. J Gallinetti 'Children's Courts' in CJ Davel \& A Skelton Commentary on the Children's Act [Original Service (2007)] paras 4.21-4.22 explains the process which led to a far more extensive proposal for provisions pertaining to legal representation for children in children's court proceedings which the South African Law Reform Commission had developed being jettisoned during the Parliamentary process and notes that this truncation has resulted in decision-making about which children qualify being left to administrative regulation rather than being formulated in clear and binding legal rules.

13 The success of the Children's Units has been indicated as a very significant highlight. See, LAB 'Legal Aid Board Annual Report 2007/2008', <http://www.legal-aid.co.za/images/2008. pdf>.

14 Ibid.

15 Regulations on the Child Care Act, 1983: Amendment Notice 416 in Gazette 18770 of 31 March 1998. These regulations provided that legal representation at the expense of the state should be provided for a child who is involved in any children's court proceedings where it is requested by the child who is capable of understanding; where it is recommended in a report by a social worker or an accredited social worker; where any other party besides the child will be legally represented in the proceedings; where it appears or is alleged that the child has been physically, emotionally or sexually assaulted, ill-treated or abused; where the child, a parent or guardian, custodian, foster parent or proposed foster parent, or an adoptive or proposed adoptive parent contests the placement recommendation of a social worker; where two or more persons are each contesting in separate proceedings for the placement of the child in their custody; where the child is capable of understanding the nature and content of the proceedings, but differences in languages used by the court and the child prevent direct communication between the court and the child, a legal representative who speaks both the languages must be provided or, where this is not possible, an alternative arrangement should be made, including the provision of an interpreter for the child; where there is reason to believe that any party to the proceedings or any witness intends to give false evidence or to withhold the truth from the court; and in any other situation where it appears that the child will benefit substantially from legal representation either as regards the proceedings themselves or as regards achieving in the proceedings the best possible outcome for the child. The regulations further provided that where legal representation at the expense of the state is not provided for any child the reasons for the decision of the children's court not to order that such legal representation be provided for the child shall be entered in the minutes of the court proceedings. 
ongoing disputes about who would pay the costs of this legal representation, given that the Department of Justice funds legal aid services, but the Child Care Act is legislation administered by the Department of Social Development. The applicable provision of the Child Care Act has consequently never been promulgated and will thus be replaced by the Children's Act provisions. However, the new Children's Act places the responsibility for the provision of legal representation to children unequivocally with the LAB.

At present, magistrates in children's court enquiries exercise their discretion in determining whether a child before them requires legal representation, which is usually in situations where there is conflict between the child and parent on issues which may result in the removal of the child from the parent, ie a foster placement or adoption. ${ }^{16}$ In such situations it is frequently the magistrate who sources such representation on behalf of the child, or the social worker acting on instruction of the magistrate. ${ }^{17}$

\section{(ii) Children's interests in other civil proceedings: curators ad litem}

A cardinal way in which children's interests have traditionally been brought to the fore in civil proceedings is through the appointment of curators ad litem. A curator ad litem is appointed by the court to conduct proceedings on behalf of another person who lacks the capacity to litigate. In the case of children, this usually occurs when the child has no guardian, or in legal proceedings where there is an actual or potential conflict of interest between the child and the child's guardian. ${ }^{18}$ The appointment of a curator is usually made by a court to represent the interests of a child (in contrast to views) where these may be affected.

Previously only the High Court could appoint a curator ad litem; however, the Magistrates Court Act 3 of 1944 in s 33 provides that a Magistrates' Court may appoint a curator ad litem in any case in which such a curator is required or allowed by law for a party to any proceedings brought or to be brought before the court. The Divorce Court Rules have a similar provision. ${ }^{19}$

In Centre for Child Law v Minister of Home Affairs, ${ }^{20}$ a distinction was drawn between a curator ad litem and a legal representative appointed in terms of s 28(1)(h). An advocate was appointed by the Court to represent the unaccompanied migrant children detained in a repatriation centre upon whose behalf a public interest body, the Centre for Child Law, had launched an application for their separation from detained adults, and for the opening of welfare proceedings prior to their deportation. The evidence was that children who are deported back to their countries of origin are loaded into trucks and taken to the train station, from where they are transported to the border, loaded onto trucks again, and taken to the nearest police station in that country. No prior

16 Interview with University law clinic children's court attorney.

17 Ibid.

18 A Skelton \& P Proudlock 'General Principles' in CJ Davel \& A Skelton Commentary on the Children's Act [Original Service (2007)] 2-23.

19 Notice 1454 in Gazette 19458 of 9 November 1998: Divorce Court Rules, s 34.

$202005(6)$ SA 50 (T). 
investigation into their home circumstances, the availability of caregivers, and so forth, preceded this operation.

The curator was able to investigate the children's situation, as well as review more generally the ongoing admission of children to the repatriation centre (para 23 of the judgment), and, notably, to apply for the appointment of legal representatives in terms of s 28(1)(h) who would in turn 'present and argue the wishes and desires of the child', thus distinguishing the role of the curator ad litem from that of a legal representative.

Du Toit v Minister of Welfare and Population Development (Lesbian and Gay Equality Project as Amicus Curiae) ${ }^{21}$ concerned a constitutional challenge to a provision of the Child Care Act 74 of 1983 prohibiting joint adoption by same sex couples. This couple had lived in partnership for more than a decade, and had adopted two children some years previously, but the law permitted only one parent, rather than both, to be awarded custody and guardianship in the adoption process. An order striking down the offending provision was sought, coupled with 'reading in' of the words 'or permanent same sex life partner' after the reference to adoption by a spouse.

A curator ad litem had, in the court a quo, filed a thorough report concerning the welfare of the couple's adoptive teenage children, and of children — born and unborn (para 3 of the judgment) - generally. The Court said that "where there is a risk of injustice, a court is obliged to appoint a curator ad litem to represent the interests of the children', noting further that this obligation flows from s 28(1)(h). However, it has been questioned whether a child's legal representative fulfils, or should equate to, a curator ad litem. ${ }^{22}$ A legal representative surely does not represent the views of 'non-clients' not before court, such as children generally, nor is it clear that all of the foreign child clients in the Centre for Child Law case would necessarily have given their representative the same brief. ${ }^{23}$

$S v M$ (Centre for Child Law as Amicus Curiae) ${ }^{24}$ involved the sentencing of a primary caregiver of young children. Being a criminal matter, s 28(1) (h) of the Constitution did not apply; however, it is submitted that the CRC and African Children's Charter rights nevertheless remained applicable. The Court was required to consider what the duties of the sentencing court are in the light of s 28(2) ('the best interests of the child') of the Constitution, when the person being sentenced is the primary caregiver of minor children, and whether these duties were observed in the case at hand.

The Centre for Child Law was appointed as amicus curiae and made written and oral submissions from a child rights perspective on the constitutional, statutory and social contexts within which the matter fell to be decided. Additionally, a curator ad litem was appointed 'to represent the interests of the children (para 31)' of the appellant. The Court did not explicitly consider whether the appointment of the curator afforded sufficient representation of

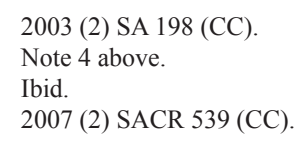


these children's views, as opposed to the children's interests. Presumably the children's views would be considered by the curator in establishing 'best interests' but the issue did not appear to be explicitly considered by the court.

In $A D v D W$ (Centre for Child Law as Amicus Curiae; Department for Social Development as Intervening Party) $)^{25}$ great reliance was placed on the report of a curator ad litem who had been appointed by the Constitutional Court. This matter dealt with an appeal from an application by an American couple to obtain sole guardianship of Baby R, in order to remove her to the United States of America, where they intended to adopt her. The matter became protracted when the couple decided to appeal the decision of the High Court, and then the decision of the Supreme Court of Appeal (SCA). Sachs J records that

[t]he report of the curatrix was particularly helpful in regard to establishing the ripeness of the matter for an expedited hearing. On the correct basis that it was Baby R's current circumstances that needed to be considered, and not her hypothetical position had the matter followed a different course, she pointed out that Baby R was now almost three years old and at a particularly significant stage in her emotional, cultural and ethical development, and her ability to adapt to change. A speedy resolution was imperative and a considerable body of reliable information had been gathered for use by the Children's Court. ${ }^{26}$

The appointment of a curator ad litem is occurring in an ever increasing number of cases where children's interests are affected, and because it is not clear how such appointee might interface with a child's legal representative, were such person also to be appointed, it seems that this issue must await judicial pronouncement.

\section{(iii) Family law matters}

Family law matters involving children are usually matters related to divorce proceedings or divorced parties where arrangements in relation to the children of the parties are in dispute. The Divorce Act 70 of 1979 permits a divorce court (ordinarily a High Court, but in future likely to be regional courts as well, once the Extension of Jurisdiction of the Regional Courts Bill, 2008 is passed) to appoint a legal practitioner to represent a child at the proceedings, and may order the parties or any one of them to pay the costs of the representation (s 6(4)). It has been noted that this provision pre-dates the constitutional right contained in s 28(1)(h), and 'raises the immediate spectre of problems occurring where the parties (ie the divorcing parents) are unable to meet such costs, since it does not provide for State-funded legal representation'. ${ }^{27}$

Indeed, the LAB Guide (2002) provides explicitly that, save with the prior written consent of the chief executive officer (CEO) of the LAB, children are not entitled to legal representation to intervene in divorce or maintenance proceedings between their parents. Nor is there (yet) express inclusion of the

26 Para 61.

27 D Kassan 'How can the Voice of the Child be Adequately Heard in Family Law Proceedings?' Unpublished LLM thesis, University of the Western Cape (2004), http://etd.uwc.ac.za/usrfiles/ modules/etd/docs/etd_init_9288_1175245869.pdf. 
'substantial injustice' test, as provided for in the constitutional provision, in the Divorce Act. It has been pointed out that courts have seldom in past years used this power to appoint legal representatives for children affected by their parent's divorce or matters incidental thereto, for example variation of custody or maintenance orders, and applications brought under the Hague Convention on the Civil Aspects of International Child Abduction (which came into effect in South Africa on 1 October 1997). ${ }^{28}$

This may have been because the Family Advocate has been regarded as notionally representing the best interests of the child: the Mediation in Certain Divorce Matters Act 24 of 1987 provides for the consideration by a court in certain circumstances of the report and recommendations of a Family Advocate before granting a decree of divorce or other relief, and provides for mediation in certain divorce proceedings, and in certain applications arising from such proceedings, such as variation, rescission or suspension of orders with regard to the custody or guardianship of minor or dependent children, in order to safeguard the interests of such children.

The courts have, however, recently begun to shift toward a stance that views the role of a legal representative of a child as distinct from that of the Family Advocate. Children's participation rights in accordance with art 12(2) of the CRC and s 28(1)(h) of the Constitution have now formally entered the judicial sphere, as some key cases illustrate. The assignment of legal representation under s 28(1)(h) fell squarely to be decided in Soller NO v G. ${ }^{29}$ The case concerned an application by a 15 year old boy for variation of a custody order that had given custody to his mother, with the father being given rights of access only. The initial application was brought on behalf of the boy by an attorney who turned out to have been struck off the roll, and was, therefore, unsuitable to act as the boy's legal representative.

The presiding judge determined that the matter required the assignment of an alternative legal representative under s 28(1)(h), concluding that such legal representative of the child did not fulfil the same role as the office of the Family Advocate. Further, any legal representative appointed to represent the child should be 'an individual with knowledge of and experience of the law but also the ability to ascertain the views of a client, present them with logical eloquence and argue the standpoint of the client in the face of doubt or opposition from an opposing party or a court'.

In the view of the Court, s 28(1)(h) does not allow for the appointment of a social worker, or psychologist or counsellor. What is required is a lawyer who will use particular skills and expertise to represent the child. 'Neutrality Convention on the Civil Aspects of International Child Abduction Act of 1997 in its entirety), a legal representative must be appointed in the same manner as provided for in s 55 of the Act for every child who is the subject of a Hague application proceeding. This dramatically changes the previous position in which the Family Advocate purported to represent the interests of the child. See further C Woodrow \& C Du Toit 'Child Abduction' in CJ Davel \& A Skelton Commentary on the Children's Act [Original Service (2007)]. 
is not the virtue desired but rather the ability to take the side of the child and act as his or her agent or ambassador. In short, a child in civil proceedings, where substantial injustice would otherwise result, must be given a voice. Such voice is exercised through the legal practitioner'. ${ }^{30}$ The judge continued to point out that the legal practitioner is not a mere mouthpiece of the child - in the course of advocating the client's views, the legal practitioner should also provide 'adult insight into those wishes' and apply legal knowledge and expertise to the child's perspective. ${ }^{31}$

Ex parte Van Niekerk: In re Van Niekerk $v$ Van Niekerk ${ }^{32}$ also concerned s 28(1)(h) directly. In an application by a father to have his rights of access to his two minor daughters confirmed, the Court made an order in terms of which the minor daughters of the two parties were allowed to intervene and to be joined as parties to the proceedings between the applicant and the respondent. Access to the children was being denied by the mother, and the parties had submitted conflicting expert reports; the Court found it impossible to find on the papers which view was correct. The Family Advocate evaluated the different reports, had consultations with the parties and the children, and was of the view that the mother was unnecessarily negative about the father and that the parties should submit to therapy to normalise the family situation, which recommendation the mother did not accept. A court order instructed the mother to take all necessary steps to persuade the children to submit to the treatment and therapy, but the children refused to submit to treatment. The mother, fearing proceedings against her for being in contempt of court, approached the Centre for Child Law, which facilitated an application for the appointment of either a legal representative in terms of s 28(1)(h) or a curator ad litem for the children. During argument, the judge indicated that in his view, rather than appoint a curator ad litem for the children, the State Attorney ought to appoint an advocate as the legal representative for the children in terms of s 28(1)(h). This was reflected in the written judgment:

The point has been made over and over that the parents accuse each other for the attitude of the children but that the children, so far, have not had an opportunity to state their views or to have their interests independently put before the court. ${ }^{33}$

It has been pointed out that although the application for appointment of a legal representative through the offices of State Attorney was successful, it unfortunately does not establish a viable model for the future, because the State Attorney, unlike the LAB, is not readily accessible to the public in general, nor particularly to children. ${ }^{34}$

The only question, the Court said, was whether the children could be joined as parties to the proceedings. In the Canadian matter of Re Children's Aid

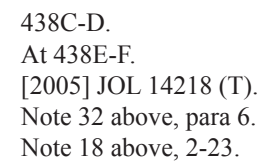


Society of Winnipeg and AM and LC Re RAM ${ }^{35}$ Matas JA, when discussing the question whether a child can be joined as a party in proceedings about his guardianship, pointed out that unless the child is a party it will be impossible for him to appeal against an order which adversely affects him.

The South African Court found that:

in my view, that is a persuasive consideration to hold that to give proper effect to the provisions of section 28(1)(h) of the Constitution a court is entitled to join minors as parties to proceedings affecting their best interests. Unless the children are joined as parties they will not be able to appeal against an adverse order. ${ }^{36}$

Again, in Rosen v Havenga ${ }^{37}$ a High Court, on its own initiative, raised the question as to whether a child whose parents were divorcing should not enjoy separate legal representation, and in this regard referred directly to the CRC and the provisions of art 12 , citing the obligation to give the child's views due weight in accordance with the age and maturity of the child. ${ }^{38}$ With no objection raised by the parties or the Family Advocate, a legal representative was appointed; and she, citing a direct and substantial interest in bringing an application for a restraining order against the defendant, successfully applied to be admitted as a party to the proceedings. This case, therefore, illustrates that more than hearing the child's voice, the child's interests became directly protected in the legal process.

$R \vee M,{ }^{39}$ also a disputed custody case, highlighted some of the practical problems that can arise. Amidst allegations of emotional instability on the part of the defendant, and sexual abuse on the part of the plaintiff, and after 22 days of expert medical and other witnesses without a conclusion to the plaintiff's argument in sight, the judge raised the issue as to whether the child (who herself displayed significant emotional instability) should not be accorded legal representation. This was agreed by all the parties, who accepted, too, that the LAB was the necessary agency to ensure the provision of legal representation in terms of $\mathrm{s} 28(1)(\mathrm{h})$ of the Constitution, but, in addition, that the complexity of the case required the appointment of counsel of seniority, with experience in matrimonial matters. But two further issues ensued. The first was an objection to the advocates appointed by the LAB, on the basis that they lacked the skill and expertise necessary. An order directing the LAB to appoint a skilled senior advocate was granted. But that ruling was set aside, as there was continuous disagreement between the parties about the adequacy, suitability and experience of the choice of counsel. ${ }^{40}$

Para 6. See A Skelton 'A Special Assignment: Interpreting The Right to Legal Representation in Terms of Section 28(1)(h) of the Constitution of South Africa' paper presented at the Miller Du Toit/ University of the Western Cape Family Law Conference, Cape Town (1-2 April 2004).

39

40

(1983) 37 R F.L. (2d) 113.

Note 32 above, para 8 .

(2006) 4 All SA 199 (C)

Case No 5493/02 Durban and Coast Local Division (unreported).

D Kassan 'Hearing Children's Voices through A Legal Representative: Proposed Guidelines Concerning when Such Legal Representation Might be Deemed Necessary or Appropriate During Divorces Proceedings in South Africa' paper presented at the 14th conference of the World Association of Youth and Family Court Judges and Magistrates, Belfast (29 August to 2 September 2006) $17-20$. 
It was noted in commentary ${ }^{41}$ that the case raised clear areas of concern: firstly, given the budgetary constraints under which the LAB operates, advocates have to agree to represent children at (public sector) legal aid tariffs, which do not match the fees most counsel charge private clients; secondly, if 'second rate' (or more junior) legal representatives intervene on children's behalf, that might diminish significantly the objective of providing equal access to justice for children. ${ }^{42}$ And thirdly, it was noted that wealthy parents might be in a position to frustrate the appointment of legal representatives for children altogether if their income is considered in the application of any means test. After some six years of extremely adversarial litigation, the LAB appointed a representative for the child. When the mother's attorneys refused to recognise this appointment, the LAB brought a successful application for a declaratory order that upheld the appointment they had made. The child finally had a legal representative, and after years of legal battles the matter reportedly settled on the second day of subsequent hearings. This illustrates cogently the need for independent legal representation for children caught up in the aftermath of divorce. Nevertheless, a legal foundation for the appointment of lawyers to represent children who are the victims of disputed custody and access arrangements which their parents take to litigation remains elusive, and, seemingly, the issue gets dealt with on an ad hoc and uneven basis.

Ford $v$ Ford $^{43}$ gave rise to questions about hearing children's views at appellate level. The matter concerned an appeal against a refusal by a High Court of first instance to grant permission for a custodian mother to relocate to the United Kingdom. The respondent had made an application at the hearing of the appeal in the SCA to hear the views of the 10-year-old child on the proposed relocation, basing this on the fact that almost three years had elapsed since the launch of the original application, and that her views might assist the Court of Appeal. He alleged that the legal basis for this application was art 12 of the CRC.

The application was rejected. The Court (per Maya AJA) agreed that the Court must take the child's wishes into account where she is old enough to articulate her preferences, but also noted that there was evidence on record that the litigation was causing her stress, and that she was 'not particularly comfortable' with being continually interviewed by experts. Further, the Court asked how it (the Court of Appeal, by definition a court of record only) was supposed to ascertain the views of the child and to record their impressions, without an intermediary, such as a psychologist, having interviewed the child properly and presented the child's views as part of expert evidence? Assuming a unanimous bench, were these views supposed to constitute evidence (having presumably not been led by counsel for either party)? Would the parties then be allowed to lead rebuttal evidence? The questions raised by Maya AJA relate to the method of hearing the child's views rather than the

41 Ibid.

42 Note 4 above.

43 Case [2005] ZASCA 123. 
principle, but nevertheless do indicate a judicial preference for indirect receipt of children's views via experts. The rights of children to be heard remains an important issue, however, and the frustration of children who wish to have an opportunity to be able put across their views needs to be kept in mind.

Some legal practitioners interviewed for the report that gave rise to this article raised a number of concerns regarding direct legal representation of children in family matters, echoing the views suggested in the Ford judgment. ${ }^{44}$ It was their view that, in most instances, legal representation may place the child in the difficult position of being in conflict with both parents, unnecessarily protract the proceedings, inflate their cost, and result in the children being interviewed by yet another person, all of which may ultimately (and paradoxically) work against the best interests of the child.

These practitioners were of the opinion that the circumstances in which legal representation per se would be called for in order properly to represent the child's views were limited, and that the child's voice in the vast majority of cases could be heard via reports of the Family Advocate, or expert witnesses, such as psychologists, called to give evidence on the child's views. The role outlined for legal representatives in Soller, ${ }^{45}$ they submitted, is, in practice a very difficult one for practitioners to follow, even if apparently mandated by s 28(1)(h) of the Constitution.

Other practitioners view the right of children to participate through direct legal representation to be very important, though there appears to be general agreement that such representation will not be necessary in every case. The LAB's application in the $R v M$ case, ${ }^{46}$ described above, demonstrates a commitment on the part of the LAB to provide legal representatives for children where such assistance is indicated, and the outcome of the case demonstrates that far from causing additional conflict, the appointment of a representative for the child may result in the resolution of the matter.

\section{(iv) Children in conflict with the law}

South Africa's Child Justice Bill 49 of 2002 originated in a 1997 Issue Paper of the South African Law Reform Commission. This was followed by a Discussion Paper in December 1998 and an extensive consultation process. A draft Child Justice Bill was produced in 2000, and a Child Justice Bill introduced in Parliament in August 2002. The Bill underwent an extensive Parliamentary process in 2003, but was unfortunately not finalised, and lay in abeyance for some years. A revised version was, however, released in December 2007, and extensive debates on the revised version occurred before the Justice and Constitutional Development Portfolio Committee. The text of the reworked version received National Assembly approval on 26 June 2008, and the stamp of approval of the National Council of Provinces was added in 
December 2008. Finalisation of the Bill in 2009, therefore, looks eminently possible. However, the date for promulgation has been set at 1 April 2010 to give government departments responsible for implementation of the legislation sufficient time to prepare.

The Bill seeks to create a separate justice system for children, embodying CRC principles and other rights. In its original form, the Bill provided that a child is entitled to legal representation in any of the procedures envisaged by the Bill. It provided that where a child is placed in detention to await trial after the preliminary enquiry (a newly introduced pre-trial case conference to determine whether prosecution on court or referral to diversion should occur), the child must be provided with legal representation at State expense and may not waive this right. Further, if the probable sentence involved a residential requirement or if the child was younger than 14 and was subject to the rebuttable presumption that he or she lacks criminal capacity, legal representation would be required. This was an explicit attempt to give content to the 'substantial injustice' test in the context of vulnerable child defendants. The original Bill further provided that only accredited legal representatives may be appointed at State expense, in an effort to promote specialisation in the representation of children.

The Bill re-introduced to Parliament in late 2007 contained some rather retrogressive provisions relevant to legal representation. First, it appeared that legal representation would not be permitted as of right at the first procedure envisaged in the proposed child justice system, namely the preliminary inquiry. Permission for a legal representative to be present would first have to be sought. Secondly, 16- and 17-year-old defendants were to be excluded from those qualifying for legal representation at State expense as of right, even where they were facing serious charges, which might result in the imposition of a custodial sentence. Submissions to the Portfolio Committee suggested that this unwarranted restriction of access to State legal aid could be unconstitutional on the basis of unfair discrimination, and moreover that it did not accord with the LAB policy developed in 2002, in terms of which all children facing the possibility of a sentence of imprisonment would enjoy legal representation at State expense, as would all those facing (presumably serious) charges in Regional and High Courts. ${ }^{47}$

47 J Sloth-Nielsen 'Submission to the Portfolio Committee on Justice and Constitutional Development: The Child Justice Bill, 2007 version' (February 2008), <http://www.childjustice.org.za/ submissions/2008Submissions/Julia\%20Sloth-Nielsen.pdf $>$. With respect to children, the Legal Aid Guide (2002) provides that the means test is based on the joint income of spouses (parents) where an application is made for legal aid for their dependent minor child, but is based on the income of the minor alone if he or she is self-supporting. The Guide also provides that for all accused legal aid applicants who qualify in terms of the means test, the legal aid officer must thereafter determine whether the accused would, if convicted, probably be sentenced to imprisonment, either with or without the option of a fine, of which the unsuspended portion would be more than three months, and if granted the option of a fine, whether such is likely to remain unpaid two weeks after imposition of sentence - this is consequently the standard of 'substantial injustice' applicable in practice (Legal Aid Guide (2002) 23-4), <http://www.legal-aid.co.za/images/lab/Legal\%20Aid\%20 Guide\%202002.pdf $>$. The requirements for legal aid are also assumed to be met if the case is to be prosecuted in the Regional or High Courts. 
Hence, it was suggested that the revised draft was less accommodating than current LAB policy.

The version tabled for voting in the House of Assembly in June 2008 has addressed these points. Firstly, it is now clarified that nothing precludes a child from enjoying the assistance of a legal representative at the preliminary inquiry (s 81). Secondly, all children whose cases are not diverted and who are referred for trial in a child justice court must be referred to the LAB, for the matter to be evaluated by the LAB, where the child is not represented by a legal representative of his or her choice and at his or her own expense (s $82(1)$ ). Section $82(2)$ provides further that no plea may be taken until the child has been afforded a reasonable opportunity to obtain a legal representative until one has been appointed. No specific references to children aged between 10 and 14 years, and subject to the rebuttable presumption that they lack criminal capacity, have been included, but this is of no consequence given that all children facing charges in court will benefit from the right to legal representation. $^{48}$

South African research conducted in 1995 showed that in over 80 per cent of cases accused persons under 18 appear before the courts unrepresented. ${ }^{49}$ Some reasons identified for this were that children claim that they were not informed about the possibility of free legal assistance, distrusted what they called 'government lawyers', proclaim that they were innocent and do not need a lawyer, say that lawyers on legal aid briefs prolong cases unnecessarily, and allege that lawyers coerce them to plead guilty. ${ }^{50}$ By 2002 it appeared that a far greater proportion of children were enjoying legal representation in criminal trials: a study for the Child Justice Alliance, involving 12 workshops with 98 children, found that 44 per cent of children in this study said they did have legal representation, and two-thirds felt that having a lawyer would positively influence the outcome of a case. Only a minority of children (34 per cent) were of the opinion that lawyers have a negative influence on the outcome of a case. ${ }^{51}$

See the minutes of the deliberations of the Portfolio Committee of 24 April 2008 on the clauses dealing with legal representation, <http://www.pmg.org.za/report/20080424-child-justice-billfurther-deliberations $>$. The argument that this leaves the determination of what in fact constitutes 'substantial injustice' will, as with the provision of the Children's Act 38 of 2005 in relation to children's court proceedings, be left to administrative regulation rather than being formulated in clear and binding legal rules, remains - see note 12 above.

49 J Raulinga, D Siditi \& T Thipanyane 'Legal Representation of Children' in L Pollecut et al Legal Rights of Children in South Africa National Institute for Public Interest Law and Research (1995) 63, 86 and 101 .

50 Lawyers for Human Rights Project 1992-94 for which 1140 accused children were interviewed, cited in the South African Law Reform Commission's Report on Juvenile Justice (2000), < http:// www.doj.gov.za/salrc/reports/r_prj106_juvjus_2000\%20jul.pdf $>$.

51 L Ehlers Children's Perspectives on the Child Justice Bill prepared for the Child Justice Alliance by The National Institute for Crime Prevention and Reintegration of Offenders (NICRO) (January 2002) 74-5. 


\section{Emergence of a Good Practice Model for Legal REPRESENTATION}

While it is evident that the international law provisions regarding legal representation and children's right to be heard in judicial proceedings are now more clearly established in the domestic arena, the question remains how those rights can be realised in a practical manner: how can legal representation be provided to children in an appropriate, cost-effective manner? Answers to this in the period immediately following the adoption of the Constitution and while the Children's Act and the Child Justice Bill were being developed were not necessarily apparent.

But it is now clear that the main role-player in providing legal representation to children in South Africa is the LAB. Consequently, the model it is attempting to follow in meeting its constitutional and legislative obligations is key; however, this article also considers the role of a number of other service providers, such as university law clinics, NGOs and private practitioners, who have historically been, and continue to be, key providers of legal services to children, whether in partnership with the LAB or independently.

\section{(a) The LAB and Children's Units}

The LAB was established in terms of the Legal Aid Act 22 of 1969, to provide for legal aid for indigent persons. The provisions of the Act have been updated in the light of the subsequent promulgation of the Constitution. ${ }^{52}$ The legislation provides that the LAB has the power, inter alia, to obtain the services of legal practitioners, to fix conditions subject to which legal aid is to be rendered, and to provide legal representation at State expense as contemplated in the Constitution. ${ }^{53}$ During the first 20 years of its existence, the LAB provided legal aid solely by means of the 'Judicare' model, ${ }^{54}$ which entailed that the LAB employed the services of lawyers in private practice to represent those needing legal aid, and compensated those lawyers according to a tariff. Many problems arose with this model, including the perception that lawyers would protract matters unnecessarily in order to inflate their fees and that only less qualified lawyers were prepared to work for the $\mathrm{LAB}^{55}$

During the 1990s the LAB became involved in a number of pilot projects in which legal aid was provided by means of salaried legal practitioners employed either directly by the LAB or by one of its cooperation partners, such as a university law clinic, through cooperation agreements. ${ }^{56}$ These agreements

$54 \mathrm{LAB}$ website (note 52 above), <http://www legal-aid.co.za/index.php/The-Legal-Aid-Board-abrief-history.html>.

55 This was cited during interviews with several private legal practitioners consulted in the course of this study, during November 2007.

56 LAB website (note 52 above), <http://www legal-aid.co.za/index.php/The-Legal-Aid-Board-abrief-history.html>. 
entailed an agreement on remuneration in exchange for a number of cases resolved by the partner, rather than remuneration on the case-by-case basis contemplated in the Judicare model. ${ }^{57}$

In 1997 the LAB decided to move towards a system of salaried legal practitioners as the main means by which legal aid would in future be provided. These legal practitioners are provided by Justice Centres located near courts, with each Centre serving between 10 and 20 courts. Each Justice Centre has a principal attorney, who is the head of the Justice Centre, professional assistants, candidate attorneys, and paralegals. Services offered by Justice Centres include advice, referrals and litigation. The LAB still has cooperation agreements with various universities that have law clinics. ${ }^{58}$ The university law clinics, in conjunction with the LAB, provide legal assistance to communities.

The primary vehicle through which the LAB is currently rolling out services to children is through Children's Units located in Justice Centres. ${ }^{59}$ These Units are to be allocated a minimum of two professional assistants (PAs), with each PA in the Unit expected to specialise in either civil or criminal representation. ${ }^{60}$ The model stipulates that PAs recruited for these Units must be admitted attorneys or advocates with at least five years' experience including experience in the representation of children. ${ }^{61}$ The Children's Unit must have links with all professional staff at the Justice Centre who are allocated matters involving the representation of children. The staff report directly to the Justice Centre Executive or a principal attorney at the Justice Centre. ${ }^{62}$ Additionally, the model stipulates that the PA specialising in the representation of children in criminal matters must also ensure that a good working relationship is developed with, amongst others, presiding officers of one-stop child Justice Centre courts, prosecutors serving in these courts, probation officers operating at these centres, Department of Correctional Services officials concerned with children awaiting trial, and the South African Police Service officials housed at the centre.

The LAB has over the period April to October 2007 represented almost 25000 children in criminal matters. ${ }^{63}$ This they have achieved through the appointment at each of the approximately 60 Justice Centres of one dedicated PA for child law. Specialists in child law are also provided by the LAB at the three one-stop child Justice Centres in the country: in Bloemfontein

59 Interview with $\mathrm{LAB}$ representative, November 2007. The motivation, as recorded in the document 'LAB Business Model — Children's Units (May 2006)' is as follows: 'The creation of Children's Units at our Justice Centres will ensure [a] dedicated focus, and will contribute greatly to the development of specialist capacity of our staff regarding child law. This dedicated focus will also cultivate in our practitioners a better understanding of how to deal with children and hence ensures that the "best interest of the child" standard is upheld"

60 Ibid.

61 Ibid.

62 Interview with LAB representative (November 2007).

63 See Table 1. 
(Mangaung); Port Nolloth (Northern Cape); and Port Elizabeth (Eastern Cape). A total of 13 such Centres are planned by the Department of Justice in urban areas across the country once the Child Justice Bill is enacted, and the LAB has capacitated the Justice Centres located in areas in which these are planned in advance with child law specialists, as it is anticipated that demand for legal services will increase once the one-stop child Justice Centres are established. $^{64}$

The LAB has planned its roll-out of child law services in Children's Units through ongoing consideration of a number of factors, including the number of arrests of children in an area, the availability of human resource capacity, and the availability of resources to support that capacity. Rural areas are currently served by satellite Justice Centres which operate under the mentorship of the main centre. Each satellite slowly expands and is capacitated until it reaches the status of a Justice Centre.

The LAB no longer relies solely on reaching children in court but undertakes ongoing prison monitoring visits in order to identify children in detention who are in need of legal representation. The Justice Centres also conduct 'Fair Play' events at schools in their communities and conduct leaflet and poster advertising campaigns to publicise the service offered to children to ensure that children are aware of the service. ${ }^{65}$

In areas where there is little or no Justice Centre capacity, the LAB still relies on Judicare agreements in terms of which private lawyers are contracted by the LAB to represent children in specific cases. Some collaboration agreements with university law clinics still exist where the performance of those clinics suggests that they are cost-effective or where there is a lack of LAB capacity. ${ }^{66}$

According to a representative of the LAB, its lawyers still encounter negative perceptions among children regarding their services, and these perceptions have limited initial expected uptake in some areas. However, it is envisaged that as the LAB expands the range and quality of its work these perceptions will become less common. A representative of the LAB suggests that it has been able to reach more children in detention by providing the services directly, and that the number of children reached by law clinics no longer yields a comparatively good return in relation to the cost to the $\mathrm{LAB}{ }^{67}$ The recent roll-out of services to children via Children's Units has had a

Ibid; LAB Business Model-Children's Units (May 2006). PAs will also be required to review the pending files of practitioners who represent children at other Magistrates' Courts so that LAB staff can provide relevant comments on these cases. This Unit must extract reports of all District Court and Regional Court matters involving children that are still pending for longer than three months and six months respectively, so that they can review delays with practitioners representing these children and determine appropriate interventions (interview with LAB representative, November 2007).

65 Ibid.

66 Ibid.

67 Note 55 above. 
significant impact on university law clinics' involvement with children in conflict with the law. The University of Cape Town (UCT) Law Clinic, like that of the University of KwaZulu-Natal (UKZN), no longer runs a child rights project and the number of cooperation agreements between the LAB and law clinics has been reduced

The combination of direct representation by the LAB, cooperation agreements and Judicare agreements, represents a pragmatic model by which the LAB attempts to provide the widest coverage of children in the most costeffective manner. By appointing specialists who receive particular training the LAB also attempts to ensure that the most vulnerable of their clients receive quality legal representation. ${ }^{68}$

\section{(b) LAB policy and children in civil proceedings}

The Legal Aid Guide provides that for the purposes of legal aid in terms of s 28(1)(h) of the Constitution, a child is not obliged to qualify for legal aid in terms of any means test if legal representation is required by or on behalf of the child in relation to civil proceedings in which the primary question in issue is the adoption of the said child, a matter involving allegations that the child is the victim of parental abuse or neglect, or a matter concerning whether the child should be placed in foster care. ${ }^{69}$

Confirming and fleshing out the principles contained in the Legal Aid Guide in relation to children's courts, the LAB Business Model Children Units (May 2006) provides for the following justiciable needs of children to be undertaken by Children's Units in relation to children's court enquiries:

- The 'best interests of the child' principle must be of paramount importance when the LAB is required to consider matters referred to it by the children's court in terms of clause 55 of the Children's Bill. The turnaround time in considering such matters should not be more than 48 hours.

- In terms of s 28(1)(h) of the Constitution, children should not be required to qualify for legal aid in terms of the means test if legal representation is required by or on behalf of a child in relation to civil proceedings where the primary issue is the adoption of the child, the matter of whether the child

68 Hence, the LAB Business Model-Children's Units provides, in relation to criminal matters involving children, that legal representatives must: ensure early contact with detained children; ensure that children who are detained are kept in appropriate facilities, such as places of safety or secure care facilities, rather than correctional facilities; ensure that every opportunity is afforded to children who are first-time offenders and who take responsibility for their actions to be diverted away from the normal court process; ensure that bail proceedings for children are conducted promptly so that they are not unnecessarily detained whilst awaiting trial; and monitor all children awaiting trial for longer than three months and ensure that appropriate interventions are put in place to address this situation with a view to having these children released or their matters brought to court without any further unnecessary delay.

69 Legal Aid Guide (2002) 20. 
is the victim of parental abuse and/or neglect, or the matter of whether the said child should be placed in foster care.

- All commissioners of children's courts must be informed of the availability of LAB lawyers to represent children in all matters where they are of the opinion that it would be in the best interests of the child that legal representation is provided to them.

- Legal representation must be provided in any adoption and foster care matter where there is disagreement by any of the parties to the adoption or foster care placement, including where the child shows reluctance as far as the adoption or foster care placement is concerned, so that the interests of the child can be protected.

The LAB Business Model further provides for various justiciable needs of children to be undertaken by Children's Units in relation to civil matters. The types of matters listed are: Hague Convention matters; appointment of curators; emancipation applications; to intervene in applications for care and contact by natural fathers; to intervene in applications for variation of custody and guardianship orders; recovering of damages on behalf of children, for example children who are victims of sexual abuse, and for personal injuries or damages claims; removal of executors where there is abuse of estate monies; recovery of funds and/or property from executors where there has been abuse of funds/property; matters relating to orphans (including foreign minors); matters aimed at protecting the rights and interests of disabled children. ${ }^{70}$

The Business Model re-iterates that legal aid will be available for children to intervene in divorce proceedings between the parents of the children only if authorised at a senior level. It is noted, though, that where only one parent is legally represented, assistance to the other parent is provided, especially if this is related to inadequate resources to obtain representation and the issue in dispute relates to the custody of, or access to, a minor child..$^{71}$ Legal aid will also generally not be available for children to intervene in maintenance proceedings between the parents of the children unless authorised by the CEO. However, if a child is a party to the proceedings, and the parent is legally represented, then the LAB should assist the child. ${ }^{72}$

The model proposes that the PA specialising in the representation of children in civil matters at the Children's Unit must review all such cases personally before allocating them to other Justice Centre staff (including candidate attorneys). ${ }^{73}$ However, a significant number of matters, especially the more complex ones, must be handled by the PA personally. ${ }^{74}$ 
This appointee must also ensure that a good working relationship is developed with, amongst others, family advocates, commissioners of children's courts, Department of Social Development officials, the Master's office, and NGOs, including advice offices within the area who work with children. ${ }^{75}$ In order to properly implement the new Children's Act, the LAB will be giving specialised training to its practitioners who practise in the children's court. ${ }^{76}$

Although there have been rapid increases off a very low base in providing legal representation services in children's court matters, the LAB has some way to go to meet this demand. During the period April to September 2007, Justice Centres dealt with a total of 1729 cases of a type which would be heard in the children's court compared with the total of 2130 for the whole of 2006/07, a projected 31 per cent year-on-year increase for the whole year (2 130 cases). ${ }^{77}$ Yet, according to the Annual Report of the Department of Justice for 2006/07, there were a total of 71942 children's court cases during the year under review and, of these, the LAB dealt with a total of 2 130, representing only 2.96 per cent of the total. ${ }^{78}$ The LAB now wishes to appoint sufficient practitioners, each of whom will have a target of finalising 150 cases per annum, based on the assumption that by 2010/11 the Children's Units will be handling 50 per cent of all cases heard in the children's court. $^{79}$

Estimates of the additional staff which will need to be hired in each year are as follows:

- $2008 / 09 \quad 52$

- $2009 / 10 \quad 120$

- 2010/11 100

Total 272

The estimated cost thereof is as follows:

- $2008 / 09$

R14 192 810,00

- 2009/10 R34 783301,00

- 2010/11 R30 783222,00

Total R79 $759333,00{ }^{80}$

\footnotetext{
Ibid 5.

Ibid.

77 Presentation by the LAB to the Children's Act Working Group meeting on the role and needs of the LAB to implement the Children's Act 38 of 2005 (9 November 2007).

80 This amount includes not only salaries, but also other items, such as the cost of additional administrative staff, rental in respect of additional office space, the additional costs of telephones, and other sundry items associated with additional staff.
}

78 Ibid.

79 Ibid. 
Table 1: Legal aid granted to children in criminal matters, April to October 2007

\begin{tabular}{|c|c|c|c|c|c|c|c|c|c|c|c|c|c|c|c|c|c|c|}
\hline \multicolumn{19}{|c|}{$\begin{array}{c}\text { LEGAL AID BOARD } \\
\text { Legal Aid granted iro Children in Criminal Matters to Children FY 07/08 }\end{array}$} \\
\hline \multirow[b]{2}{*}{ Prov } & \multirow[b]{2}{*}{ Justice Center } & \multicolumn{7}{|c|}{ Granted Internal } & \multirow[b]{2}{*}{$\begin{array}{c}\text { Granted } \\
\text { - Internal } \\
\text { Total }\end{array}$} & \multicolumn{7}{|c|}{ Granted - Judicare } & \multirow[b]{2}{*}{$\begin{array}{c}\text { Granted } \\
\text { - Judicare } \\
\text { Total }\end{array}$} & \multirow[b]{2}{*}{$\begin{array}{c}\text { Grand } \\
\text { Total }\end{array}$} \\
\hline & & 4 & 5 & 6 & 7 & 8 & 9 & 10 & & 4 & 5 & 6 & 7 & 8 & 9 & 10 & & \\
\hline \multirow[t]{11}{*}{ KwaZulu Natal } & Durban JC & 129 & 104 & 89 & 137 & 112 & 128 & 123 & 822 & 3 & & & & 1 & 10 & 4 & 18 & 840 \\
\hline & Empangeni JC & 41 & 46 & 42 & 39 & 54 & 50 & 64 & 336 & & & & & 3 & & & 3 & 339 \\
\hline & Ladysmith JC & & 2 & & 6 & 2 & & 1 & 11 & & & & & & & & & 11 \\
\hline & NewCastle JC & 32 & 27 & 57 & 37 & 41 & 20 & 53 & 267 & & 8 & 1 & 1 & & 4 & 5 & 19 & 286 \\
\hline & Pietermaritzburg JC & 76 & 121 & 30 & 153 & 101 & 164 & 111 & 756 & 1 & 1 & & 1 & 3 & 5 & & 11 & 767 \\
\hline & Pinetown JC & 68 & 114 & 94 & 102 & 94 & 205 & 97 & 774 & 3 & & 1 & & 12 & 7 & 2 & 25 & 799 \\
\hline & Port Shepstone JC & 84 & 72 & 36 & 38 & 62 & 53 & 79 & 424 & & 7 & 8 & 2 & 1 & 4 & & 22 & 446 \\
\hline & Umlazi JC & 62 & 64 & 55 & 54 & 44 & 26 & 61 & 366 & 1 & 1 & & 3 & 4 & 1 & 3 & 13 & 379 \\
\hline & Verulam JC & 158 & 203 & 62 & 168 & 157 & 21 & 123 & 892 & 2 & 4 & 1 & 1 & 6 & 21 & 14 & 49 & 941 \\
\hline & Vryheid JC & 25 & 65 & 55 & 47 & 105 & 81 & 44 & 422 & 1 & & 1 & & & 6 & 4 & 12 & 434 \\
\hline & KwaZulu Natal Total & 675 & 818 & 520 & 781 & 772 & 748 & 756 & 5,070 & 11 & 21 & 12 & 8 & 30 & 58 & 32 & 172 & 5,242 \\
\hline \multirow[t]{8}{*}{ Western Cape } & Athlone JC & 74 & 99 & 181 & 111 & 144 & 221 & 200 & 1,030 & 3 & 8 & 10 & 2 & 2 & 2 & & 27 & 1,057 \\
\hline & Caledon JC & 26 & 40 & 24 & 25 & 36 & 33 & 45 & 229 & & & & & & 1 & & 1 & 230 \\
\hline & Cape Town JC & 44 & 104 & 115 & 138 & 220 & 129 & 132 & 882 & 2 & 4 & 2 & 3 & 3 & 3 & 5 & 22 & 904 \\
\hline & George JC & 52 & 256 & 224 & 91 & 124 & 124 & 98 & 969 & 26 & 14 & 13 & 10 & 24 & 27 & 21 & 135 & 1,104 \\
\hline & Stellenbosch JC & 149 & 163 & 115 & 161 & 106 & 209 & 132 & 1,035 & 1 & 2 & 4 & 5 & 1 & 4 & 6 & 23 & 1,058 \\
\hline & Vredendal JC & 19 & 50 & 32 & 20 & 35 & 28 & 36 & 220 & 2 & 1 & 6 & 4 & 2 & 5 & 7 & 27 & 247 \\
\hline & Worcester JC & 84 & 87 & 167 & 91 & 68 & 149 & 72 & 718 & 5 & 8 & 13 & 6 & 23 & 2 & 18 & 75 & 793 \\
\hline & Western Cape Total & 448 & 799 & 858 & 637 & 733 & 893 & 715 & 5,083 & 39 & 37 & 48 & 30 & 55 & 44 & 57 & 310 & 5,393 \\
\hline
\end{tabular}




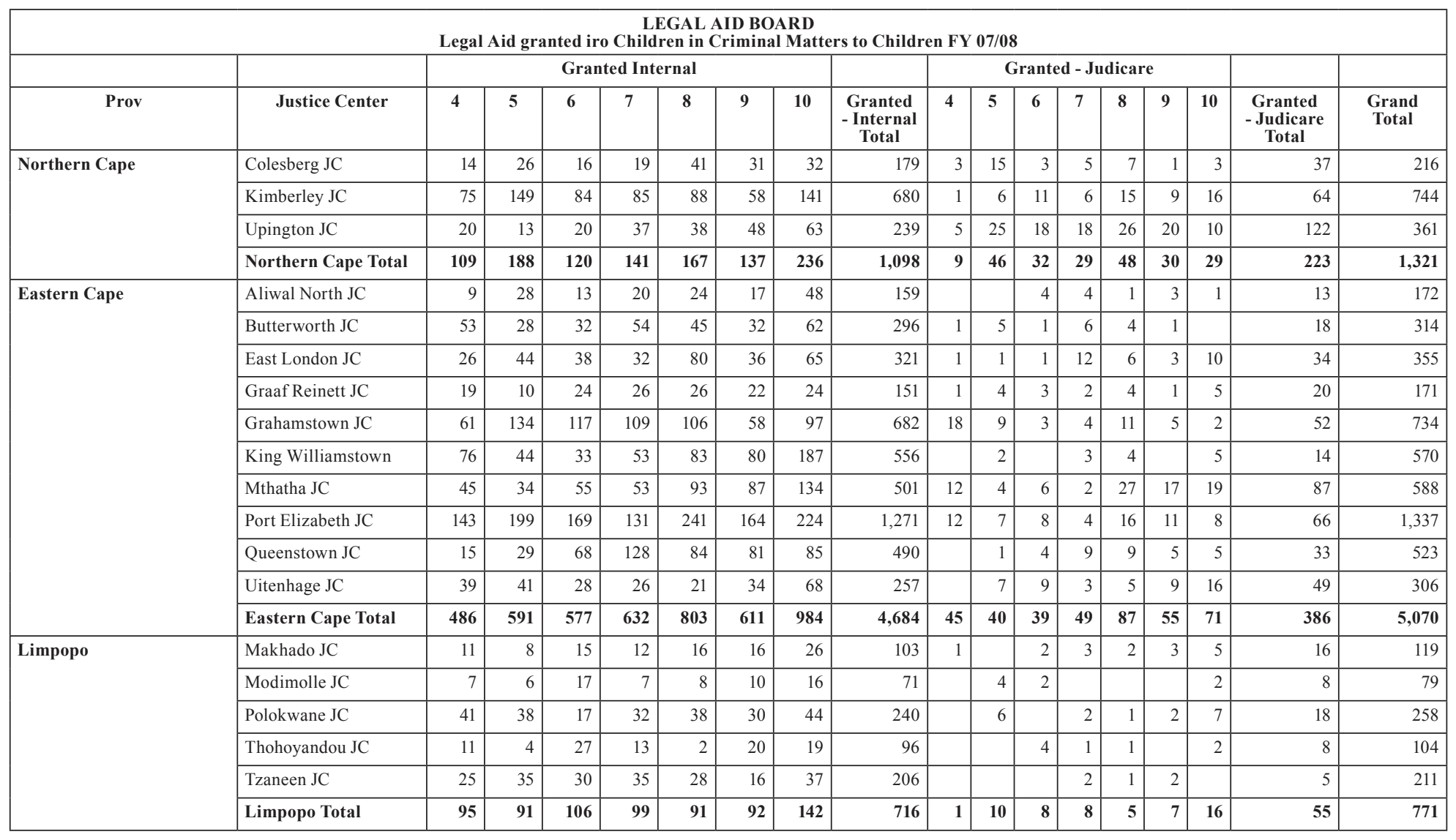




\begin{tabular}{|c|c|c|c|c|c|c|c|c|c|c|c|c|c|c|c|c|c|c|}
\hline \multicolumn{19}{|c|}{$\begin{array}{c}\text { LEGAL AID BOARD } \\
\text { Legal Aid granted iro Children in Criminal Matters to Children FY } 07 / 08\end{array}$} \\
\hline \multirow[b]{2}{*}{ Prov } & \multirow[b]{2}{*}{ Justice Center } & \multicolumn{7}{|c|}{ Granted Internal } & \multirow[b]{2}{*}{$\begin{array}{c}\text { Granted } \\
\text { - Internal } \\
\text { Total }\end{array}$} & \multicolumn{7}{|c|}{ Granted - Judicare } & \multirow[b]{2}{*}{$\begin{array}{c}\text { Granted } \\
\text { - Judicare } \\
\text { Total } \\
\end{array}$} & \multirow[b]{2}{*}{$\begin{array}{c}\text { Grand } \\
\text { Total }\end{array}$} \\
\hline & & 4 & 5 & 6 & 7 & 8 & 9 & 10 & & 4 & 5 & 6 & 7 & 8 & 9 & 10 & & \\
\hline \multirow[t]{5}{*}{ Free State } & Bloemfontein JC & 24 & 16 & 18 & 10 & 7 & 35 & 14 & 124 & 6 & 17 & 2 & 4 & & & 5 & 34 & 158 \\
\hline & Kroonstad JC & 6 & 20 & 9 & 19 & 17 & 16 & 21 & 108 & 2 & 2 & 7 & 5 & 12 & 8 & 4 & 40 & 148 \\
\hline & Phuthaditjhaba JC & 42 & 16 & 19 & 53 & 23 & 63 & 37 & 253 & & 2 & & 3 & 6 & 3 & 1 & 15 & 268 \\
\hline & Welkom JC & 16 & 47 & 23 & 27 & 63 & 34 & 48 & 258 & 16 & 6 & 3 & 5 & 12 & 12 & 12 & 66 & 324 \\
\hline & Free State Total & 88 & 99 & 69 & 109 & 110 & 148 & 120 & 743 & 24 & 27 & 12 & 17 & 30 & 23 & 22 & 155 & 898 \\
\hline \multirow[t]{9}{*}{ Gauteng } & Alexandra JC & 19 & 23 & 13 & 22 & 22 & 20 & 22 & 141 & & & & 1 & 1 & 6 & 1 & 9 & 150 \\
\hline & Benoni JC & 32 & 29 & 27 & 89 & 108 & 70 & 76 & 430 & & 8 & 6 & 6 & 2 & 25 & 6 & 53 & 483 \\
\hline & Germiston JC & 10 & 26 & 35 & 25 & 34 & 32 & 37 & 199 & 6 & 1 & 4 & 9 & 8 & 13 & 10 & 51 & 250 \\
\hline & Johannesburg JC & 17 & 4 & 9 & 15 & 29 & 12 & 16 & 102 & 2 & 3 & & 2 & 1 & & 13 & 21 & 123 \\
\hline & Krugersdorp JC & 50 & 99 & 57 & 122 & 71 & 84 & 73 & 556 & 7 & & 5 & 3 & 10 & 3 & 6 & 34 & 590 \\
\hline & Pretoria JC & 30 & 32 & 37 & 29 & 40 & 34 & 55 & 257 & 3 & 1 & 1 & & & 7 & 12 & 24 & 281 \\
\hline & Soweto JC & 88 & 90 & 55 & 80 & 322 & 96 & 62 & 793 & & & & & 4 & 2 & 2 & 8 & 801 \\
\hline & Vereeniging JC & 53 & 46 & 72 & 45 & 87 & 53 & 64 & 420 & 3 & 7 & 6 & 1 & 4 & 2 & 3 & 26 & 446 \\
\hline & Gauteng Total & 299 & 349 & 305 & 427 & 713 & 401 & 404 & 2,898 & 21 & 20 & 22 & 22 & 30 & 58 & 53 & 226 & 3,124 \\
\hline \multirow[t]{8}{*}{ North West } & Ga-Rankuwa JC & 33 & 19 & 5 & 26 & 22 & 6 & 33 & 143 & 4 & 4 & 1 & 10 & 6 & 3 & & 28 & 171 \\
\hline & Klerksdorp JC & 33 & 26 & 34 & 57 & 23 & 100 & 50 & 323 & 3 & 3 & 27 & 1 & 4 & 6 & 1 & 45 & 368 \\
\hline & Lichtenburg JC & 25 & 32 & 8 & 34 & 21 & 49 & 42 & 211 & 4 & 11 & 12 & 6 & 13 & 15 & & 61 & 272 \\
\hline & Mafikeng JC & 12 & 5 & 20 & 22 & 12 & 16 & 53 & 140 & & & & 1 & 2 & 1 & & 4 & 144 \\
\hline & Potchefstroom JC & 68 & 63 & 75 & 103 & 47 & 84 & 109 & 549 & 1 & & 1 & 1 & 7 & 1 & 2 & 13 & 562 \\
\hline & Rustenburg JC & 23 & 28 & 9 & 38 & 22 & 16 & 66 & 202 & 1 & & 9 & 8 & & & & 18 & 220 \\
\hline & Vryburg JC & 11 & 27 & 17 & 22 & 45 & 31 & 40 & 193 & 4 & 11 & 5 & 18 & 14 & 2 & 2 & 56 & 249 \\
\hline & North West Total & 205 & 200 & 168 & 302 & 192 & 301 & 393 & 1,761 & 17 & 29 & 55 & 45 & 46 & 28 & 5 & 225 & 1,986 \\
\hline
\end{tabular}




\begin{tabular}{|c|c|c|c|c|c|c|c|c|c|c|c|c|c|c|c|c|c|c|}
\hline \multicolumn{19}{|c|}{$\begin{array}{c}\text { LEGAL AID BOARD } \\
\text { Legal Aid granted iro Children in Criminal Matters to Children FY } 07 / 08\end{array}$} \\
\hline \multirow[b]{2}{*}{ Prov } & \multirow[b]{2}{*}{ Justice Center } & \multicolumn{7}{|c|}{ Granted Internal } & \multirow[b]{2}{*}{$\begin{array}{c}\text { Granted } \\
\text { - Internal } \\
\text { Total } \\
\end{array}$} & \multicolumn{7}{|c|}{ Granted - Judicare } & \multirow[b]{2}{*}{$\begin{array}{c}\text { Granted } \\
\text { - Judicare } \\
\text { Total }\end{array}$} & \multirow[b]{2}{*}{$\begin{array}{c}\text { Grand } \\
\text { Total }\end{array}$} \\
\hline & & 4 & 5 & 6 & 7 & 8 & 9 & 10 & & 4 & 5 & 6 & 7 & 8 & 9 & 10 & & \\
\hline \multirow[t]{5}{*}{ Mpumalanga } & Ermelo JC & 17 & 15 & 11 & 27 & 13 & 11 & 19 & 113 & & & & & 1 & 2 & 12 & 15 & 128 \\
\hline & Middleburg JC & 22 & 13 & 18 & 32 & 24 & 12 & 28 & 149 & & 2 & 5 & 3 & & 1 & 1 & 12 & 161 \\
\hline & Nelspruit JC & 42 & 23 & 21 & 41 & 14 & 20 & 34 & 195 & 1 & 2 & 4 & 14 & 1 & 5 & 1 & 28 & 223 \\
\hline & Witbank JC & 34 & 31 & 25 & 68 & 86 & 37 & 98 & 379 & 3 & 6 & 2 & 9 & 14 & 6 & 5 & 45 & 424 \\
\hline & Mpumalanga Total & 115 & 82 & 75 & 168 & 137 & 80 & 179 & 836 & 4 & 10 & 11 & 26 & 16 & 14 & 19 & 100 & 936 \\
\hline \multicolumn{2}{|l|}{ Grand Total } & 2,520 & 3,217 & 2,798 & 3,296 & 3,718 & 3,411 & 3,929 & 22,889 & 171 & 240 & 239 & 234 & 347 & 317 & 304 & 1,852 & 24,741 \\
\hline
\end{tabular}

Table 2: Legal aid granted to children in civil matters, April to October 2007

\begin{tabular}{|c|c|c|c|c|c|c|c|c|c|c|c|c|c|c|c|c|c|c|}
\hline \multicolumn{19}{|c|}{$\begin{array}{c}\text { LEGAL AID BOARD } \\
\text { Legal Aid granted iro Children in Civil Matters Per Region FY 07/08 }\end{array}$} \\
\hline \multirow[b]{2}{*}{ Prov } & \multirow[b]{2}{*}{ Justice Center } & \multicolumn{7}{|c|}{ Granted Internal } & \multirow[b]{2}{*}{$\begin{array}{c}\text { Granted } \\
\text { - Internal } \\
\text { Total }\end{array}$} & \multicolumn{7}{|c|}{ Granted - Judicare } & \multirow[b]{2}{*}{$\begin{array}{c}\text { Granted } \\
\text { - Judicare } \\
\text { Total } \\
\end{array}$} & \multirow[b]{2}{*}{$\begin{array}{c}\text { Grand } \\
\text { Total }\end{array}$} \\
\hline & & 4 & 5 & 6 & 7 & 8 & 9 & 10 & & 4 & 5 & 6 & 7 & 8 & 9 & 10 & & \\
\hline \multirow[t]{8}{*}{ Kwa-Zulu Natal } & Durban JC & 103 & 48 & 61 & 60 & 35 & 32 & 28 & 367 & & 1 & & & 2 & 14 & 1 & 18 & 385 \\
\hline & Empangeni JC & 1 & 15 & 2 & 5 & 3 & 5 & 1 & 32 & & & & 1 & & & & 1 & 33 \\
\hline & Ladysmith JC & 3 & 4 & 2 & 5 & 47 & 3 & 4 & 68 & & & & & & & & & 68 \\
\hline & NewCastle JC & 4 & 9 & 7 & 7 & 3 & 1 & 5 & 36 & & & & 2 & 2 & 3 & 1 & 8 & 44 \\
\hline & \begin{tabular}{|l|} 
Pietermaritzburg JC \\
\end{tabular} & 21 & 25 & 11 & 22 & 20 & 14 & 13 & 126 & & & 7 & 1 & 2 & & 3 & 13 & 139 \\
\hline & Pinetown JC & 8 & 3 & 4 & 1 & 2 & 2 & 2 & 22 & & 5 & 2 & 2 & 3 & 1 & 2 & 15 & 37 \\
\hline & Port Shepstone JC & 11 & 117 & 14 & 31 & 42 & 8 & 13 & 236 & & 10 & 2 & 3 & & & 1 & 16 & 252 \\
\hline & Umlazi JC & 6 & 33 & 6 & 16 & 11 & 6 & 12 & 90 & & & & & & & 1 & 1 & 91 \\
\hline
\end{tabular}




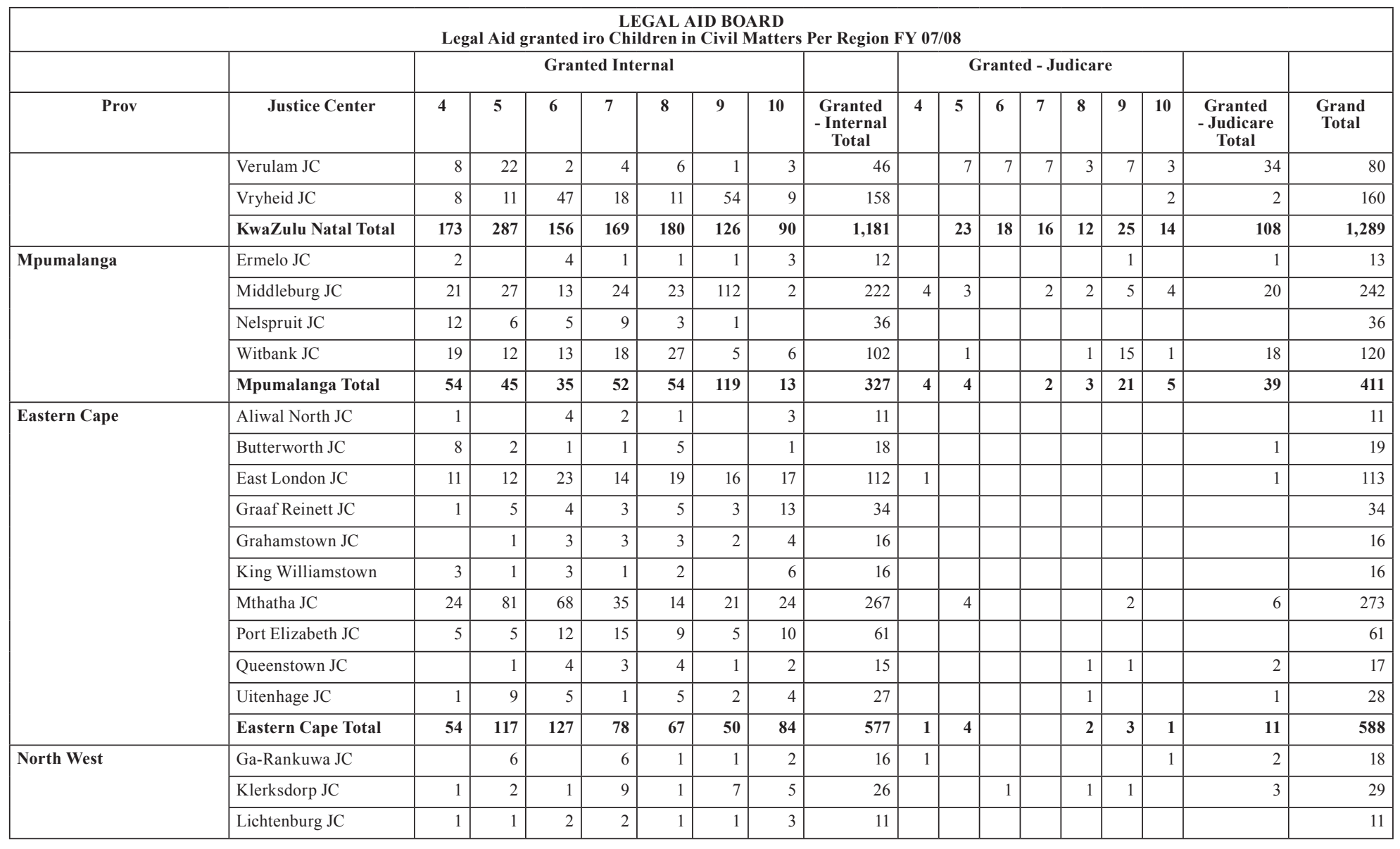




\begin{tabular}{|c|c|c|c|c|c|c|c|c|c|c|c|c|c|c|c|c|c|c|}
\hline \multicolumn{19}{|c|}{$\begin{array}{l}\text { LEGAL AID BOARD } \\
\text { Legal Aid granted iro Children in Civil Matters Per Region FY 07/08 }\end{array}$} \\
\hline \multirow[b]{2}{*}{ Prov } & \multirow[b]{2}{*}{ Justice Center } & \multicolumn{7}{|c|}{ Granted Internal } & \multirow[b]{2}{*}{$\begin{array}{c}\text { Granted } \\
\text { - Internal } \\
\text { Total }\end{array}$} & \multicolumn{7}{|c|}{ Granted - Judicare } & \multirow[b]{2}{*}{$\begin{array}{l}\text { Granted } \\
\text { - Judicare } \\
\text { Total }\end{array}$} & \multirow[b]{2}{*}{$\begin{array}{c}\text { Grand } \\
\text { Total }\end{array}$} \\
\hline & & 4 & 5 & 6 & 7 & 8 & 9 & 10 & & 4 & 5 & 6 & 7 & 8 & 9 & 10 & & \\
\hline & Mafikeng JC & 7 & 15 & 11 & 19 & 13 & 11 & 10 & 86 & & & & & & & & & 86 \\
\hline & Potchefstroom JC & 1 & & 3 & 2 & 1 & 3 & 3 & 13 & & & & & & & & & 13 \\
\hline & Rustenburg JC & 5 & 8 & 1 & 3 & 4 & & 6 & 27 & 1 & & 1 & & & & 1 & 3 & 30 \\
\hline & \begin{tabular}{|l|} 
Vryburg JC \\
\end{tabular} & & 2 & 2 & 1 & 2 & 1 & 1 & 9 & 1 & & & & & 1 & & 2 & 11 \\
\hline & North West Total & 15 & 34 & 20 & 42 & 23 & 24 & 30 & 188 & 3 & & 2 & & 1 & 2 & 2 & 10 & 198 \\
\hline \multirow[t]{6}{*}{ Limpopo } & Makhado JC & 32 & 4 & 3 & 4 & 2 & 6 & 9 & 60 & & & & & & & & & 60 \\
\hline & Modimolle JC & 1 & 2 & & & & & 1 & 4 & & & & & & & & & 4 \\
\hline & Polokwane JC & 3 & 4 & 2 & 4 & 1 & & 1 & 15 & & & & & & & & & 15 \\
\hline & Thohoyandou JC & 7 & 3 & 17 & 9 & 18 & 18 & 11 & 83 & & & & & & & & & 83 \\
\hline & Tzaneen JC & 12 & 6 & 3 & 3 & 6 & & 3 & 33 & & & & & & & 1 & 1 & 34 \\
\hline & Limpopo Total & 55 & 19 & 25 & 20 & 27 & 24 & 25 & 195 & & & & & & & 1 & 1 & 196 \\
\hline \multirow[t]{9}{*}{ Gauteng } & Alexandra JC & 5 & 8 & 3 & 8 & 5 & 12 & 4 & 45 & & & & 1 & & & & 1 & 46 \\
\hline & \begin{tabular}{|l|} 
Benoni JC \\
\end{tabular} & 8 & 12 & 3 & 14 & 12 & 3 & 5 & 67 & 1 & & & & & 1 & & 2 & 59 \\
\hline & Germiston JC & 1 & 7 & 6 & 2 & 3 & 2 & & 21 & 2 & 2 & & & 1 & 5 & 2 & 12 & 33 \\
\hline & Johannesburg JC & 34 & 19 & 14 & 39 & 20 & 32 & 25 & 183 & 54 & 41 & 35 & 18 & 19 & 17 & 32 & 216 & 399 \\
\hline & Krugersdorp JC & 8 & 7 & 6 & 8 & 7 & 6 & 10 & 52 & & 1 & 1 & 1 & 1 & 1 & 2 & 7 & 59 \\
\hline & Pretoria JC & 20 & 32 & 17 & 54 & 43 & 19 & 20 & 205 & 4 & 3 & 3 & 6 & 9 & 10 & 10 & 45 & 250 \\
\hline & Soweto JC & 1 & & & & 1 & & 1 & 3 & & & & & & & 1 & 1 & 4 \\
\hline & Vereeniging JC & 16 & 10 & 8 & 9 & 9 & 4 & 9 & 65 & & & & 2 & 3 & 1 & & 6 & 71 \\
\hline & Gauteng Total & 93 & 95 & 57 & 134 & 100 & 78 & 74 & 631 & 61 & 47 & 39 & 28 & 33 & 35 & 47 & 290 & 921 \\
\hline
\end{tabular}




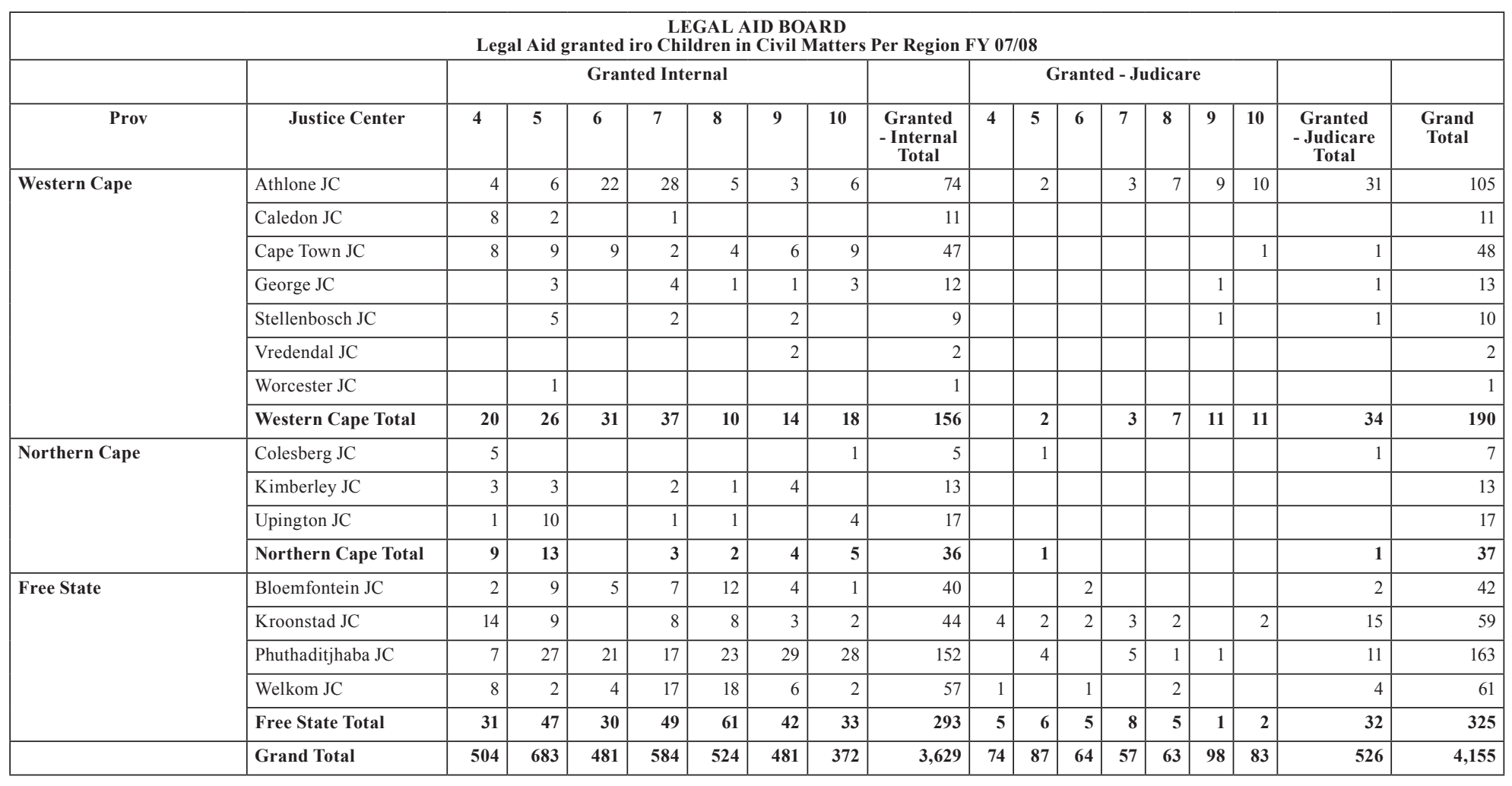




\section{(c) University law clinics}

University law clinics are one conduit through which children - both those accused of crimes and those who are the subject of children's court enquiries - have historically accessed legal representation. One example of this model of practice was the Child Rights Project of the UKZN Law Clinic, established in 1997. The Project arose out of a survey among detained youth, conducted by the Clinic at the Youth Detention Centre closest to this university, which confirmed earlier studies indicating that many children in detention did not trust lawyers provided by the State, and were thus unrepresented. The Project conducted weekly visits to the local Detention Centre to identify children in need of legal representation (at the time LAB attorneys tended only to be accessible at court). The advantage of this approach was that the Project was able to consult with clients and 'establish a relationship of trust' prior to the next appearance in court and adequate time could be spent on consultation. This sourcing method also resulted in children most in need - ie those actually in detention - being recipients of the service provided. The Project made a point of participating in children's activities at the Detention Centre in order to become familiar and trusted faces among the children in detention. ${ }^{81}$

The UKZN Child Rights Project did not confine itself to providing legal services for children, but also engaged in advocacy work. It was funded by international donor organisations and also via cooperation agreements with the LAB, but is no longer funded due to the LAB's new model. The UCT Law Clinic also operated a Child Justice Project which represented children in criminal proceedings, and their LAB funding has also now been withdrawn. The model followed by the UCT Project was to be present in juvenile court continuously, so that when a child who was unrepresented appeared, the magistrate would stand the matter down to the end of the roll to permit the UCT legal representative time to consult with the child; at the end of the day the matter was re-called. ${ }^{82}$ According to a former UCT Law Clinic attorney, 'the children never refused us. They wanted us to represent them'.

University law clinics have also played a role in children's court matters. For example, the University of the Western Cape and UCT Law Clinics have in the past frequently been contacted by the presiding magistrate in Wynberg children's court to represent children in children's court enquiries. In more recent years, magistrates have tended to contact the LAB to represent a child in children's court, possibly due to the fact that the LAB has now prioritised this type of representation and made available child law specialists who are able to consult with the child where they are, whether that is at school, in therapy or with the social worker. Cooperation agreements with some university law clinics in relation to children's courts have been discontinued - for example, that of UCT - which has lead to university law clinics concentrating their efforts in other areas where they have funding. Some have raised 
concerns about this development. 'It is of concern to me that the same LAB Justice Centre can represent both the child and the parents in children's court. Surely this is a conflict of interest?' said a former UCT Law Clinic children's court attorney.

Although university law clinics do provide services in children's courts outside of agreements with the LAB, these agreements are one of the primary means by which law clinics are able to fund their work. The current cooperation partners and the total number of matters taken on by them (all matters - adults and children) appear in Table 3 (source: LAB Annual Report 2006/7). ${ }^{83}$ This information indicates that there is potentially still a substantial role for university law clinic to play in providing additional legal services to children.

Table 3: LAB cooperation agreements new matters 2006/7

\begin{tabular}{|l|l|r|}
\hline Name of Co-operation Partner & Province & $\begin{array}{l}\text { New Matters } \\
\mathbf{2 0 0 6 / 0 7}\end{array}$ \\
\hline University of Pretoria & Gauteng & 640 \\
\hline Wits Law Clinic & Gauteng & 1,425 \\
\hline KwaZulu-Natal Land Legal Cluster & KwaZulu-Natal & 159 \\
\hline Campus Law Clinic & KwaZulu-Natal & 135 \\
\hline Mpumalanga Land Legal Cluster & Mpumalanga & 194 \\
\hline Free State Rural Development Association & Free State & 368 \\
\hline Free State University & Free State & 1,459 \\
\hline University of the Western Cape & Western Cape & 512 \\
\hline University of Stellenbosch & Western Cape & 576 \\
\hline Total Co-operation Partners New Matters & & $\mathbf{5 , 4 6 8}$ \\
\hline
\end{tabular}

\section{CONCLUSION}

While South Africa still has some way to go to ensuring that children's rights to legal representation and to be heard are fully implemented in relation to judicial proceedings affecting them, some promising practices have emerged which point to an ongoing expansion of the realisation of these rights. This article has charted some key developments in law, policy and implementation that underscore this. The analysis also illustrates that apart from merely serving as the child's voice in the courtroom setting, effective child lawyering is also contingent on a commitment to seeking out children in need of services, on an emphasis more broadly on stakeholder relationships in the sector, and on a willingness to adjust to changing circumstances.

83 A number of NGOs outside of university law clinics per se provide legal services to children. A number of these also focus on impact litigation. These include Lawyers for Human Rights, the Legal Resources Centre, and the Centre for Child Law, all of which are registered as law clinics in their own right. Their role in providing legal representation for children falls outside the scope of this article. 